\title{
Mouse Model of OPRM1 (A118G) Polymorphism Increases Sociability and Dominance and Confers Resilience to Social Defeat
}

\author{
Lisa A. Briand, ${ }^{1,3 *}$ Monica Hilario, ${ }^{1 \star}$ Holly C. Dow, ${ }^{2}$ Edward S. Brodkin, ${ }^{2}$ Julie A. Blendy, ${ }^{1}$ and Olivier Berton ${ }^{2}$ \\ ${ }^{1}$ Department of Pharmacology and ${ }^{2}$ Department of Psychiatry, Perelman School of Medicine at the University of Pennsylvania, Philadelphia, Pennsylvania \\ 19104, and ' Department of Psychology, Temple University, Philadelphia, Pennsylvania 19122
}

\begin{abstract}
A single nucleotide polymorphism (SNP) in the human $\mu$-opioid receptor gene (OPRM1 A118G) has been widely studied for its association in drug addiction, pain sensitivity, and, more recently, social behavior. The endogenous opioid system has been shown to regulate social distress and reward in a variety of animal models. However, mechanisms underlying the associations between the OPRM1 A118G SNP and these behaviors have not been clarified. We used a mouse model possessing the human equivalent nucleotide/amino acid substitution to study social affiliation and social defeat behaviors. In mice with the Oprm1 A112G SNP, we demonstrate that the G allele is associated with an increase in home-cage dominance and increased motivation for nonaggressive social interactions, similar to what is reported in human populations. When challenged by a resident aggressor, G-allele carriers expressed less submissive behavior and exhibited resilience to social defeat, demonstrated by a lack of subsequent social avoidance and reductions in anhedonia as measured by intracranial self-stimulation. Protection from social defeat in G-allele carriers was associated with a greater induction of c-fos in a resilience circuit comprising the nucleus accumbens and periaqueductal gray. These findings led us to test the role of endogenous opioids in the $\mathrm{A} 112 \mathrm{G}$ mice. We demonstrate that the increase in social affiliation in $\mathrm{G}$ carriers is blocked by pretreatment with naloxone. Together, these data suggest a mechanism involving altered hedonic state and neural activation as well as altered endogenous opioid tone in the differential response to aversive and rewarding social stimuli in G-allele carriers.
\end{abstract}

Key words: anhedonia; intracranial self-stimulation; $\mu$-opioid; OPRM1 A118G; social defeat; social interaction

\section{Introduction}

Social interactions, both positive and negative, are critical for survival. The experience of positive social interactions, such as social reward and attachment, impact our well-being and impairments are often seen in psychiatric disorders (American Psychiatric Association, 2013). Furthermore, the experience of negative social interactions, such as social rejection, can lead to social withdrawal, impulsivity, substance abuse, anxiety, and depression (Baumeister et al., 2005; Williams, 2007; Mallott et al., 2009; Slavich et al., 2010). $\mu$-Opioid receptors (MOPRs) are integrally involved in the modulation of both positive and negative affective states, including social reward and rejection (Trezza et al., 2011; Hsu et al., 2013). During periods of positive social interaction,

Received Nov. 12, 2014; revised Dec. 22, 2014; accepted Dec. 31, 2014.

Author contributions: L.A.B., M.H., E.S.B., J.A.B., and 0.B. designed research; L.A.B., M.H., and H.C.D. performed research; L.A.B. and M.H. analyzed data; L.A.B., J.A.B., and O.B. wrote the paper.

This work was supported by grants from the National Institutes of Health (K99DA033372 to L.A.B.; R01MH087581 to 0.B.; R01DA033646, R21-DA-027066 to J.A.B.; and P50MH096891-6773 and R01MH080718 to E.S.B). We thank Jenny Xiang and Mike Spadola for technical assistance.

*L.A.B. and M.H. contributed equally to this work.

The authors declare no competing financial interests.

Correspondence should be addressed to Julie A. Blendy, PhD, Center for Neurobiology and Behavior, University of

Pennsylvania, Translational Research Laboratory, 125 South 31st Street, Philadelphia, PA 19104. E-mail: blendy@mail.med.upenn.edu.

DOI:10.1523/JNEUROSCI.4685-14.2015

Copyright $\odot 2015$ the authors $\quad 0270-6474 / 15 / 353582-09 \$ 15.00 / 0$ endogenous opioids may contribute to the rewarding aspects of these interactions (Herman and Panksepp, 1978). Furthermore, social isolation leads to a relative decrease in opioid release, which may increase the motivation to seek out social interaction (Panksepp et al., 1978; Knowles et al., 1989; Kalin et al., 1995).

Genetic mutations of the MOPRs that alter receptor function can influence social behavior in a variety of animal models and humans (Moles et al., 2004; Barr et al., 2008). The nonsynonymous single nucleotide polymorphism (SNP) A118G within the MOPR gene (OPRM1) is commonly seen in European (15-30\%) and Asian (49-60\%) populations (Bergen et al., 1997; Gelernter et al., 1999; Tan et al., 2003). Individuals that carry the G allele have an increased tendency to become engaged in affectionate relationships and experience more pleasure in social situations (Troisi et al., 2011). Furthermore, G-allele carriers seem more resilient in the face of aversive maternal care environments, exhibiting less fearful attachment behavior (Troisi et al., 2012). On the other hand, G-allele carriers have also been shown to exhibit increased sensitivity to social rejection (Way et al., 2009; Bertoletti et al., 2012). These differences may be mediated by the complicated genetic background and reliance on self-report questionnaires to evaluate social reward and rejection. To clarify the functional mechanisms linking the OPRM1 A118G SNP in social behavior phenotypes, we used a mouse model possessing the equivalent SNP in the mouse Oprm1 gene (A112G). These mice reproduce 
many of the phenotypic hallmarks of humans with the A118G SNP (Mague and Blendy, 2010). The present study used this mouse model to determine the role of this polymorphism in both positive and negative social interactions and to further examine neural substrates underlying these behaviors.

\section{Materials and Methods}

Animals. The derivation of the OPRM1 A112G mouse was accomplished using site-directed mutagenesis in a bacterial artificial chromosome containing the C57BL/6 mouse Oprm1 gene. Adenine at position 112 was replaced with a guanine, resulting in an asparagine to aspartic acid substitution (for detailed description of generation of Oprm1 ${ }^{\text {tm1Jabl }}$ mice, see Mague et al., 2009). This amino acid change eliminated an N-linked glycosylation site (Huang et al., 2012), similar to the effect of the A118G SNP found in humans. Mice were generated using C57BL/6 ES cells (Millipore Bioscience Research Reagents) and maintained on this strain background through heterozygous matings. All experiments used adult male and female mice ( $\sim 20$ weeks old; $20-35$ g; of either the A/A or G/G genotypes) maintained on a $12 \mathrm{~h}$ light/dark cycle with food and water available ad libitum in accordance with the University of Pennsylvania Animal Care and Use Committee. Animals were housed with siblings of mixed genotypes (A/A, A/G, G/G) in groups of 3-5 mice. All experimental testing sessions were conducted during the light phase of the light/ dark cycle, between 9:00 A.M. and 5:00 P.M.

Three-chamber sociability test. The tendency to seek social interaction or sociability was measured as previously described by Brodkin et al. (2004). Briefly, male and female adult mice were placed in a threecompartment box with two perforated Plexiglas cylinders (diameter, 3 inches; height, 4.9 inches; hole diameter, 0.5 inch) with removable, black Plexiglas lids, one in each of the side chambers. Animals were allowed to explore the three compartments and the two empty cylinders for $10 \mathrm{~min}$ (Phase 1). Then a 3-4-week-old DBA/2J stimulus mouse of the same sex was placed in one of the cylinders and an object was placed in the other cylinder. Animals were allowed to have a $10 \mathrm{~min}$ visual, auditory, and olfactory interaction (Phase 2). All behavioral testing was videotaped with a Sony Digital Video Camera with NightShot feature for recording in low light. The time spent sniffing the stimulus mouse in the cylinder was measured, as it has been previously shown to be a direct and sensitive measure of sociability (Moy et al., 2007). All testing was conducted in dim light conditions (1-2 lux). In the naloxone experiment, mice were injected with either naloxone hydrochloride $(0.1 \mathrm{mg} / \mathrm{kg}$, s.c.; SigmaAldrich) or saline $10 \mathrm{~min}$ before Phase 1 of the social-approach test.

Olfactory acuity test. Three days before the test, mice of both genotypes were exposed to peanut butter chips in their home cage to acclimatize them to the novel food. Mice were food deprived overnight before the test. On test day, mice were individually transferred to a clean holding cage for $5 \mathrm{~min}$, before the food stimulus was placed in the cage. The food stimulus (a peanut butter chip) was buried in one corner of the cage and the mouse was placed at the opposite end. Latency to begin consuming the peanut butter chip was measured by an observer blind to genotype.

Surgical procedures. Animals were anesthetized with 1-3\% isoflurane in oxygen and positioned in a stereotaxic frame (Kopf Instruments). Stainless steel bipolar stimulating electrodes (6 $\mathrm{mm}$ in length) were lowered into the medial forebrain bundle at the level of the lateral hypothalamus [MFB; coordinates anteroposterior: $-1.9 \mathrm{~mm}$ from bregma; mediolateral: $\pm 0.8 \mathrm{~mm}$; dorsoventral: $-4.8 \mathrm{~mm}$ from skull surface; flat-skull position, according to Paxinos and Franklin (2004)]. Electrodes were secured with one skull screw and dental acrylic. Following implantation, animals were group housed (four animals per cage) and allowed to recover for 1 week before intracranial self-stimulation (ICSS) training. Any mice that lost or dislodged their cap/electrode assemblies were discarded from the study $(N=2)$. The ICSS experimental apparatus consisted of six Plexiglas operant chambers $(15.9 \times 14.0 \times 12.7 \mathrm{~cm}$; Med Associates), encased individually in a sound-attenuating box $(55.9 \times$ $38.1 \times 35.6 \mathrm{~cm}$ ). Each chamber had a metal wheel manipulandum (width, $3.8 \mathrm{~cm}$; response registered for every $90^{\circ}$ of rotation) extending $1.5 \mathrm{~cm}$ out of one of the walls. Animals were connected to the stimulation circuit by flexible bipolar leads (Plastics One) and gold-contact swivel commutators. Brain stimulation was delivered by constant current stimulators (Stimteck 1200, San Diego Instruments). The stimulation parameters, data collection, and all programming functions were controlled by a microcomputer.

ICSS. For the ICSS procedure, male mice were trained in operant chambers (Med Associates) using a modified discrete-trial currentthreshold procedure. Current-intensity thresholds were used as a measure of reward. Each testing session was $\sim 45 \mathrm{~min}$ in duration. Response latencies were defined as the time that elapsed between the onset of the noncontingent stimulus and a positive response. The response latency for each test session was defined as the mean response latency of all trials. Baseline activity of brain reward systems remain stable following repeated exposures to ICSS (Carlezon and Chartoff, 2007). Stable ICSS reward thresholds were defined as $\leq 10 \%$ variation in thresholds over a $3 \mathrm{~d}$ period, which was established after $10-14 \mathrm{~d}$ of training.

Social-defeat stress. To ensure stable ICSS baselines in a novel context, before social defeat (SD), mice were submitted to 8 consecutive days of sensory exposure with CD1 aggressor mice using a perforated Plexiglas partition dividing the resident home cage in two halves, allowing visual and olfactory contact between animals. Every day, the experimental mice were exposed to sensory contact with a novel mouse. Following context habituation, mice were submitted to SD stress for 4 consecutive days. Every day, each experimental mouse was introduced into the home cage of an unfamiliar resident for $4 \mathrm{~min}$ and was physically defeated. Resident aggressor mice were $\mathrm{CD} 1$ breeders selected for their attack latencies that were reliably shorter than $30 \mathrm{~s}$ upon three consecutive screening tests. After 5 min of physical interaction, intruders were tested for their ICSS thresholds and then housed in sensory contact with the aggressor through a perforated Plexiglas partition. Intruder mice were exposed to a new resident aggressor mouse each day. The nondefeated control animals were individually housed without any contact with aggressor mice. The interaction test was performed as previously described (Berton et al., 2007). Briefly, both naive male control mice and male mice exposed to the $4 \mathrm{~d}$ defeat procedure were allowed to habituate to and explore the testing arena; a white plastic open field $(42 \times 42 \mathrm{~cm})$, which contained an empty removable wire mesh Plexiglas box $(10 \times 6.5 \mathrm{~cm})$ located at one end of the field ("no-target" condition). After $2.5 \mathrm{~min}$, the experimental mouse was removed from the arena and placed back into its home cage for $\sim 1$ min, while a CD1 male aggressor was placed inside the Plexiglas box. The experimental mouse was moved back in the arena and its trajectories were recorded for $2.5 \mathrm{~min}$ ("target" condition). A videotracking system was used to record and analyze the time spent in the "interaction zone" ( $8 \mathrm{~cm}$ perimeter surrounding the Plexiglas cage) during the "no target" and "target" conditions. In addition, time spent in the corners opposite to the location of the box and total locomotion were also recorded. The interaction score was calculated as $100 \times$ interaction time, target present)/(interaction time, target absent).

Tube test. To determine the social dominance of A/A and G/G mice, we used the social-dominance tube test (Messeri et al., 1975). A clear Plexiglas tube (diameter, 2 inches; length, 12 inches) was placed in an empty standard cage. For 2 consecutive days, each mouse was trained four times per day to move quickly and directly through the clear tube. A mouse was placed at one end and guided into the tube. If the mouse stopped in the tube and stayed in one position past $2 \mathrm{~min}$, the mouse was pushed out of the tube by a small probe. The cage and tube were cleaned after each trial. After the $2 \mathrm{~d}$ training period, social dominance was evaluated over the following $3 \mathrm{~d}$. All mice within the same homecage were tested pairwise using a round robin design. Two mice were guided into opposing ends of the tube. The mouse that forced its opponent out backwards from the tube was proclaimed the winner of that specific trial. If the two mice remained in the tube past $2 \mathrm{~min}$, the mice were removed from the tube and the trial was conducted again. The cage and tube were cleaned after each trial. The percentage trials won by each mouse was calculated as a measure of social dominance.

Resident-intruder test. Naive male A/A and G/G mice were introduced into the home cage of an unfamiliar resident aggressor for $4 \mathrm{~min}$ and were physically defeated as described above. This session was videotaped and the number of times the resident attacked the experimental mouse as well 
as the number of times the experimental mouse approached the aggressor was tallied.

Tissue collection. Thirty minutes following an acute SD experience, naive mice were deeply anesthetized with sodium pentobarbital (10 $\mathrm{mg} / \mathrm{kg}$ ) and transcardially perfused with $30 \mathrm{ml}$ of PBS followed by $40 \mathrm{ml}$ of $4 \%$ paraformaldehyde in PBS. The brains were removed and placed in the same fixative overnight at $4^{\circ} \mathrm{C}$. The brains were then placed in a solution of $30 \%$ sucrose in PBS containing $0.1 \%$ sodium azide at $4^{\circ} \mathrm{C}$ for $\geq 48 \mathrm{~h}$. Forty micron sections from regions of interest were placed in PBS with $0.1 \%$ sodium azide and stored at $4^{\circ} \mathrm{C}$ until further processing.

Immunohistochemistry. Before immunohistochemical labeling, sections were incubated for $20 \mathrm{~min}$ in $0.75 \% \mathrm{H}_{2} \mathrm{O}_{2}$ in PBS followed by several rinses in PBS. Sections were then rinsed several times with PBS containing $0.3 \%$ Triton $\mathrm{X}-100$ (PBST), 0.04\% bovine serum albumin (BSA) before incubation in rabbit anti-Fos (Abcam). Sections were incubated for $3 \mathrm{~d}$ at $4^{\circ} \mathrm{C}$ in Fos primary antisera (1:1000) diluted in PBST plus BSA containing $0.1 \%$ sodium azide $(\mathrm{PBST}+\mathrm{BSA})$. Sections were rinsed several times in PBST + BSA before 90 min incubation in secondary antisera (1:200, biotinylated donkey anti-rabbit; Jackson ImmunoResearch). Following additional rinses, sections were incubated in avidin-biotin complex (ABC elite kit, Vector Laboratories) for 90 min. Following PBS rinses, sections were incubated for $5 \mathrm{~min}$ in $0.04 \% 3,3^{\prime}$ diaminobenzidine- $4 \mathrm{HCl}$ (Sigma-Aldrich) containing $0.01 \% \mathrm{H}_{2} \mathrm{O}_{2}$ and $0.06 \%$ nickel sulfate in Tris buffer for a black reaction product that was terminated by rinses in PBS. Immunoreactivity was visualized using a Nikon Eclipse E600 microscope and images were captured with a QImaging Retiga 1300 using Image-Pro Plus software (MediaCybernetics). Fos-immunolabeled cells from each brain region were quantified using ImageJ software. Counts were taken bilaterally from two sections per mouse and averaged (averaging a total of four counts). The person quantifying was blind to group assignments. Anatomical regions were identified according to the stereotaxic atlas of Franklin and Paxinos (2007).

Data analysis. All analyses were performed using GraphPad Prism 5.0 software package (GraphPad Software). ICSS and behavioral data were analyzed using one-way ANOVA with Newman-Keuls post hoc or twoway ANOVA with Bonferroni's post hoc as appropriate. For all ICSS data, threshold and response latency was expressed as percentage of baseline values obtained during the last four daily sessions before the first sensory social exposure. The number of c-Fos-labeled cells in each brain region was determined for each animal. Group differences in c-Fos immunoreactivity were assessed using two-way ANOVAs with condition (defeat stress vs control) and genotype as the independent variables and number of cells as the dependent variable. Bonferroni's post hoc comparisons were conducted when main effects or interactions were present. Statistical significance for all tests was set at $\alpha=0.05$.

\section{Results}

G/G mice exhibited increased social affiliation

To evaluate motivation for positive social interactions, the tendency to seek social interaction with a nonaggressive juvenile social target was measured using a three-chamber socialapproach test in naive mice. No differences were seen between the social-affiliation behavior in males versus females, so the sexes were combined for the analyses $(N=10-12$ per sex; total of 20-22 per genotype). Both male and female G/G mice exhibited an increase in social affiliation as evidenced by an increase in time spent sniffing the social cylinder compared with the A/A mice (Fig. $1 a$; effect of cylinder, $F_{(1,38)}=74.00, p<0.0001$; effect of genotype, $F_{(1,38)}=14.00, p=0.0007$; interaction, $F_{(1,38)}=7.30$, $p=0.01$; Bonferroni's post hoc test, social cylinder A/A vs G/G, $p<0.0001)$. No differences were seen in the time spent sniffing empty cylinders (Fig. 1b). Additionally, to confirm that these differences in social affiliation are not due to differences in olfactory acuity, we measured the amount of time it took mice to reach an appetitive olfactory stimulus and found no differences between A/A and G/G mice (latency: A/A, $16.8 \pm 2.97, n=8 ; \mathrm{G} / \mathrm{G}$, $14.9 \pm 2.44, n=9)$.

\section{G/G mice exhibit blunted social avoidance following SD stress}

To evaluate the impact of a negative social experience, we examined social interactions in naive mice following a $4 \mathrm{~d}$ SD paradigm. Pilot data revealed a sensitized response to defeat. Therefore we used a shorter SD exposure (only $4 \mathrm{~d}$ ) to avoid a floor effect. SD induced a decrease in the time spent in the interaction zone regardless of genotype (main effect of stress, $F_{(1,40)}=$ $12.0, p=0.001$ ). This effect was driven primarily by the A/A mice, as there was no difference seen in the time spent in the interaction zone between control and defeated G/G mice (Fig. $2 a$; Bonferroni's post hoc, Control vs SD A/A: $p=0.001$; G/G: $p=0.40$ ). Additionally, defeated A/A mice spent more time in the corners during the interaction test, whereas defeated G/G mice did not (Fig. $2 b$; effect of stress, $F_{(1,40)}=7.0, p=0.008$; interaction, $F_{(1,40)}=$ 5.0, $p=0.03$; Bonferroni's post hoc, Control vs SD A/A: $p=0.002$; $\mathrm{G} / \mathrm{G}: p>0.99)$. Genotype had no influence on behavior when no target was present during the interaction test.

\section{G/G mice exhibit blunted anhedonia following SD stress}

Naive A/A and G/G male mice were implanted with electrodes and trained to acquire an operant response to deliver stimulation to the MFB. No differences were seen between genotypes during the ICSS training phase. Upon stabilization ICSS current thresholds were recorded in A/A $(n=9)$ and $\mathrm{G} / \mathrm{G}(n=8)$ mice during baseline ( $4 \mathrm{~d}$ before any social or environmental changes), as well as during sensory exposure to CD1 aggressor $(8 \mathrm{~d})$ and $\mathrm{SD}(4 \mathrm{~d}$; Fig. $3 a$ ). No differences were seen between $A / A$ and G/G in baseline ICSS thresholds $(A / A=120 \pm 12 ; G / G=130 \pm 12)$. Analysis of the thresholds during the sensory exposure and SD phase re- 

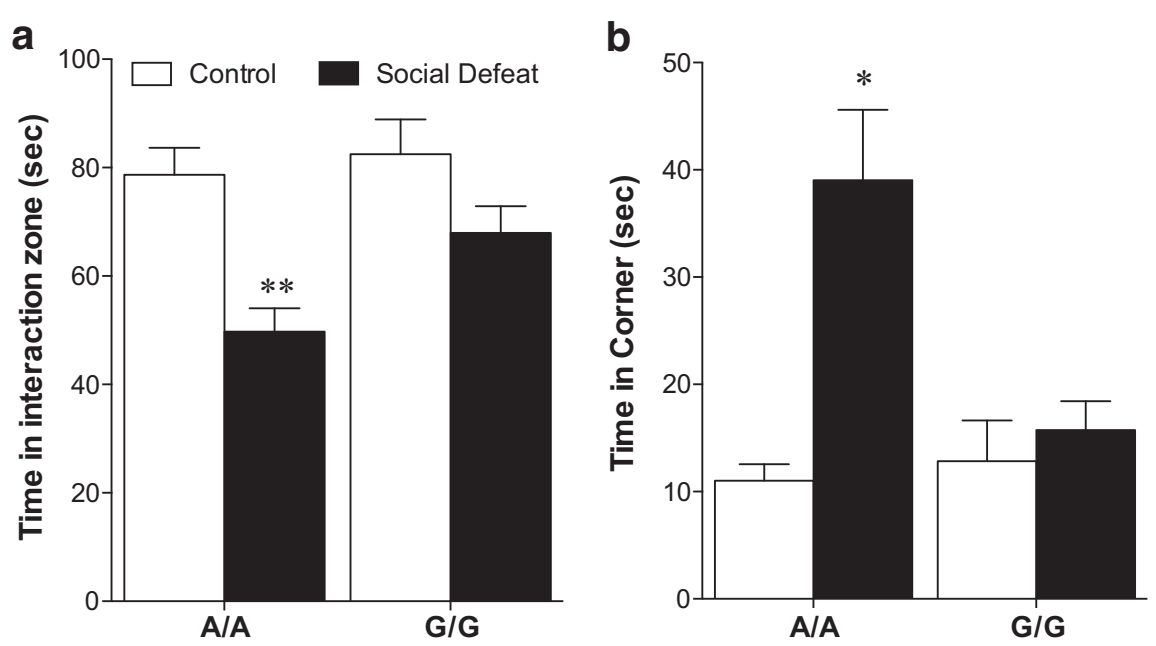

Figure 2. G/G mice exhibit decreased SD behavior compared with A/A mice. $\boldsymbol{a}$, While socially defeated A/A mice exhibit decreased time in the interaction zone compared with nondefeated control $\mathrm{A} / \mathrm{A}$ mice, $\mathrm{G} / \mathrm{G}$ mice do not exhibit a significant decrease in social interaction following SD. $\boldsymbol{b}$, Furthermore, defeated A/A mice spend significantly more time in the corners during the interaction test, whereas defeated $\mathrm{G} / \mathrm{G}$ mice do not. ${ }^{*} p<0.05,{ }^{* *} p<0.01$ pairwise comparison defeated $\mathrm{A} / \mathrm{A}$ versus control $\mathrm{A} / \mathrm{A}$.

\section{a Experimental Design}

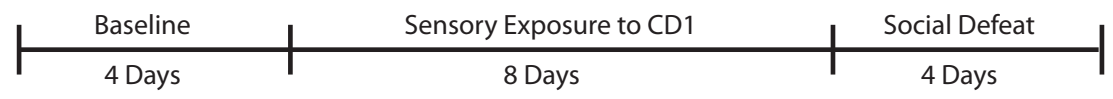

\section{b ICSS Reward Thresholds}

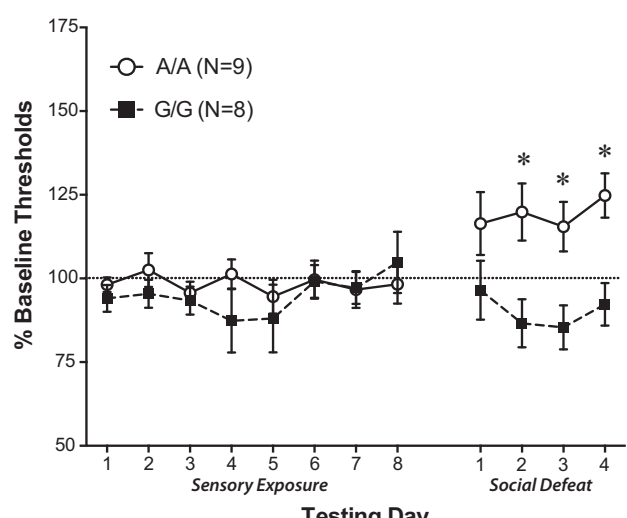

Testing Day
C Regression Analysis

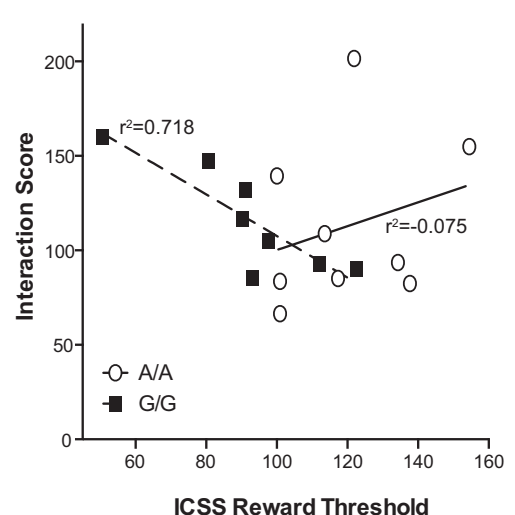

Figure 3. $G / G$ mice do not exhibit anhedonia following SD stress. $\boldsymbol{a}$, Experimental design. $\boldsymbol{b}$, Whereas SD experience led to an increase in ICSS reward thresholds in the A/A mice, $G / G$ mice did not exhibit a significant change in reward threshold. Instead they exhibited a trend toward a decrease. No differences were seen between the genotypes following the sensory exposure to the aggressor before the SD experience. c, Furthermore, there is a correlation in the $\mathrm{G} / \mathrm{G}$ mice between ICSS reward threshold and behavior in the social-interaction test following SD, with higher levels of social interaction associated with lower reward thresholds. This correlation was not present in the A/A mice. ${ }^{*} p<0.05$ significantly different from average ICSS threshold during sensory exposure.

vealed that defeat led to an increase in reward thresholds in the $\mathrm{A} / \mathrm{A}$ mice. No change in reward threshold was evident in $\mathrm{G} / \mathrm{G}$ mice (Fig. $3 b$; effect of day, $F_{(11,165)}=2.0, p=0.036$; interaction between day and genotype, $F_{(11,165)}=3.6, p=0.0001$; Bonferroni's post hoc test, A/A SD day 4 vs All sensory exposure days, A/A vs $\mathrm{G} / \mathrm{G}, \mathrm{SD}$ day $2-4, p<0.05)$. We ran a regression model with ICSS threshold as the outcome variable and genotype, social avoidance, and a genotype $\times$ social-avoidance interaction as predictors. The interaction was significant $(b=-0.77, t=2.94, p=$ 0.01 ), suggesting that genotype moderates the relationship between social avoidance and ICSS threshold. Specifically, the correlation between social-avoidance behavior and ICSS threshold was found to be significant for $\mathrm{G} / \mathrm{G}$ mice $\left(r^{2}=0.72\right.$, $p=0.008)$, but not for A/A mice $\left(r^{2}=\right.$ $0.075, p=0.48)$.

Compared with A/A mice, G/G mice exhibit increased social dominance and decreased retreat when exposed to a resident aggressor

Within their homecage group, G/G mice exhibit greater social dominance as evidenced by an increase in the percentage of tube-test trials won against cage mates (Fig. $4 a ; t_{(13)}=3.1, p=0.008$ ). Additionally, when naive $G / G$ mice were exposed to resident aggressors, they elicited more attack behavior from resident aggressors and exhibited higher levels of approach behavior compared with A/A mice, indicating decreased submissive behavior (Fig. $4 b, c ; b$, $t_{(18)}=2.1 ; p=0.047 ; c, t_{(18)}=2.4 ; p=$ $0.029)$.

\section{G/G mice exhibit decreased c-Fos} immunoreactivity following acute SD While both G/G and A/A mice exhibit significant increases in c-Fos protein following SD stress, the $\mathrm{G} / \mathrm{G}$ mice exhibit an exaggerated response within the core of the nucleus accumbens (NAc core; Fig. $5 b$; effect of stress, $F_{(1,18)}=120, p<0.0001$; interaction, $F_{(1,18)}=17.69, p=0.0005$; post hoc stress G/G vs A/A $p<0.0001$ ), lateral septum (Fig. $5 d$; stress, $F_{(1,18)}=$ $210, p<0.0001$; interaction, $F_{(1,18)}=66$, $p<0.0001$; post hoc stress G/G vs A/A $p<$ $0.0001)$, basolateral amygdala (BLA; Fig. $5 e$; stress, $F_{(1,18)}=57, p<0.0001$; interaction, $F_{(1,18)}=18, p=0.0007$; post hoc stress $G / G$ vs A/A $p<0.0001$ ), paraventricular nucleus of hypothalamus [PVN, Fig. 5f; stress, $F_{(1,18)}=61, p<0.0001$; interaction, $F_{(1,18)}=7.8, p=0.013$, post hoc stress $\mathrm{G} / \mathrm{G}$ vs $\mathrm{A} / \mathrm{A} p=0.002)$, and the periaqueductal gray (PAG, Fig. $5 g$; stress, $F_{(1,18)}=67, p<0.0001 ;$ interaction, $F_{(1,18)}=5.5, p<0.03$; post hoc stress $\mathrm{G} / \mathrm{G}$ vs A/A, $p=0.007)$. SD stress also led to an increase in c-Fos response within the anterior cingulate and NAc shell, but no differences were seen between the genotypes (Fig. 5a,c).

\section{Increased social affiliation in G/G mice is blocked by naloxone treatment}

We have shown that G/G mice exhibit conditioned aversion to naloxone, in the absence of morphine treatment (Mague et al., 2009), suggesting a greater level of endogenous opioids. As social behaviors can be modulated by endogenous opioids (Chaijale et al., 2013), we hypothesized that differences in social behavior in G/G mice might be due to an increase in endogenous opioid 

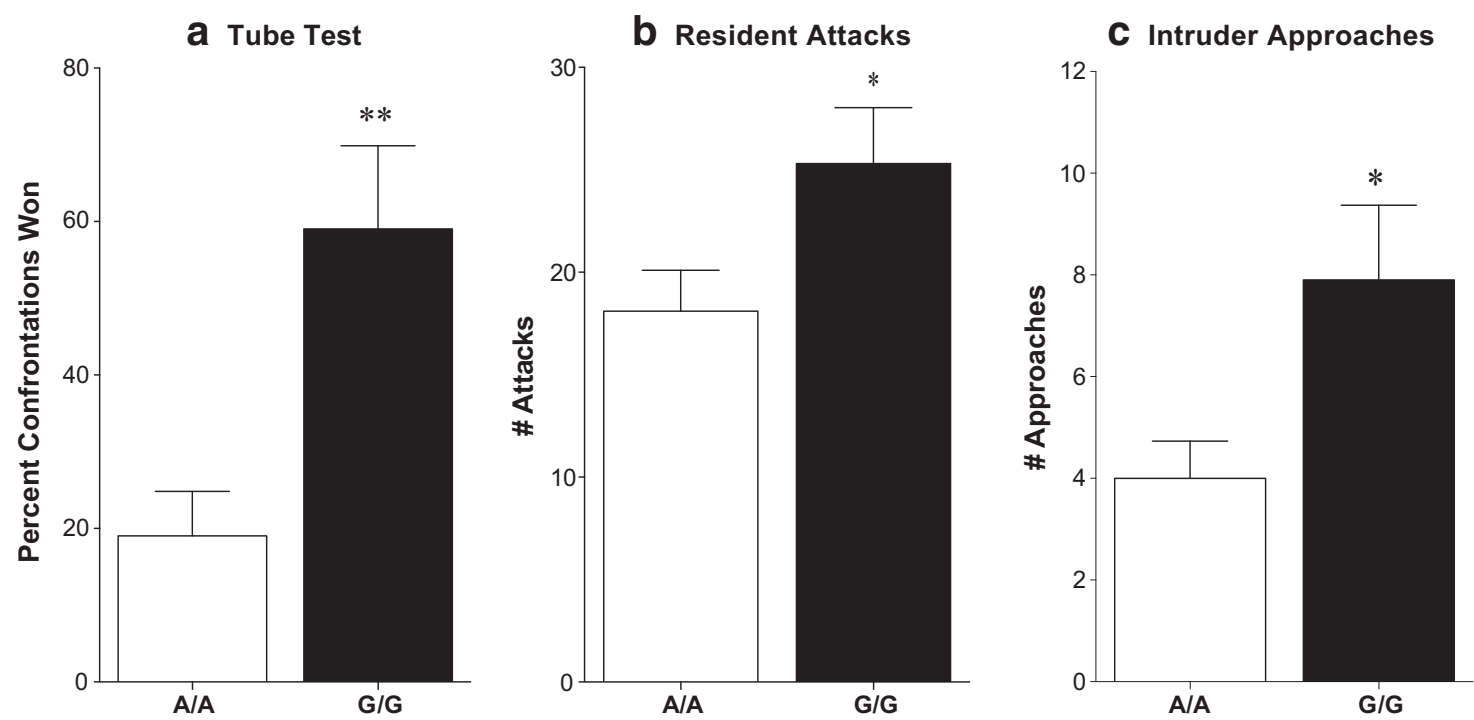

Figure 4. $G / G$ mice are more socially dominant and exhibit less submissive behavior when exposed to a $C D 1$ aggressor. $\boldsymbol{a}, \mathrm{G} / \mathrm{G}$ mice won a greater percentage of confrontations in the social dominance tube test than $A / A$ mice. $\boldsymbol{b}, \boldsymbol{c}$, Indicative of decreased submissive behavior when exposed to an aggressor, $G / G$ mice elicit more attacks $(\boldsymbol{b})$ and engage in more approach behavior (c) than the $\mathrm{A} / \mathrm{A}$ mice. ${ }^{*} p<0.05,{ }^{* *} p<0.01 \mathrm{G} / \mathrm{G}$ versus $\mathrm{A} / \mathrm{A}$.

a Anterior Cingulate

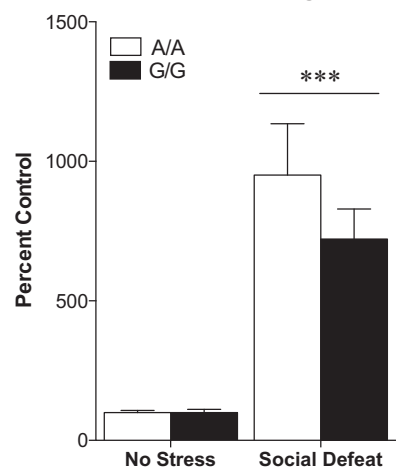

b Nac Coret

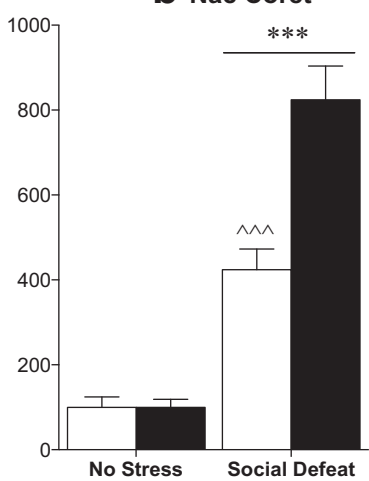

C Nac Shell

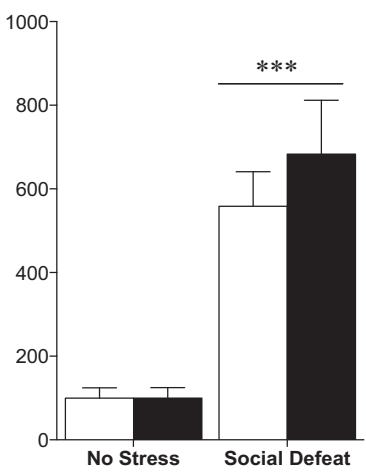

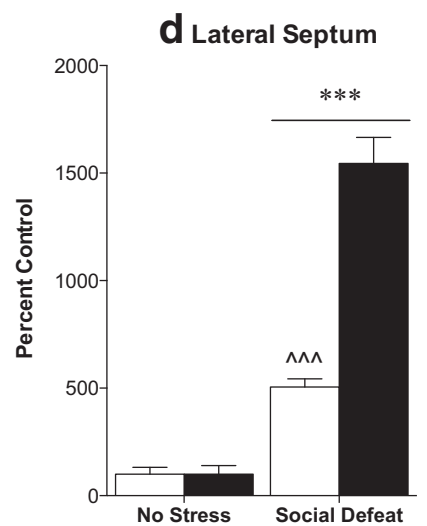
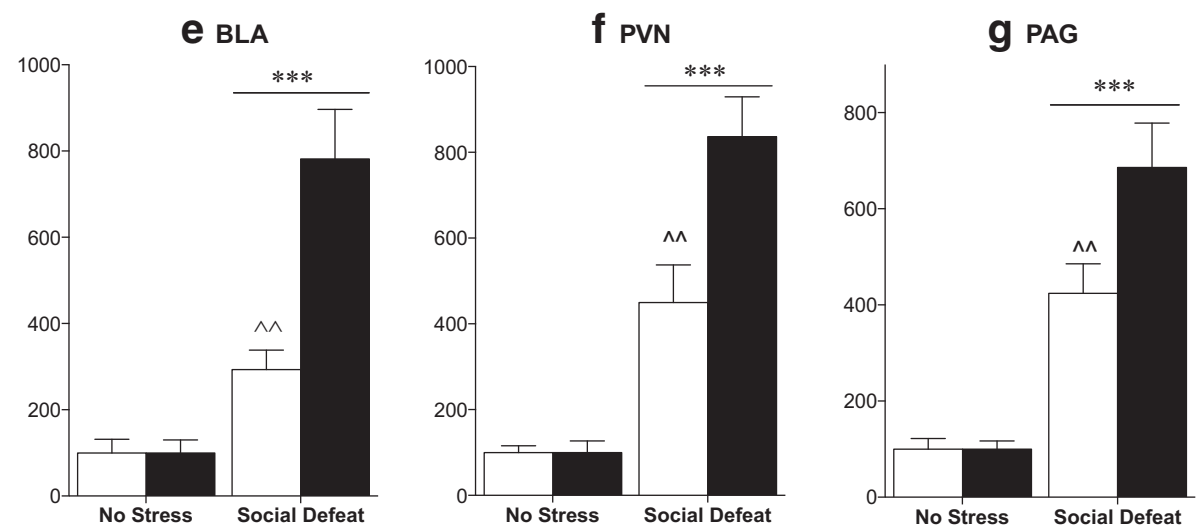

Figure 5. $G / G$ mice exhibit increased Fos protein expression in response to $S D$ stress. $\boldsymbol{a}-\boldsymbol{g}$, Both $A / A$ and $G / G$ mice exhibit a significant increase in Fos protein following a single $S D$ stress in within the anterior cingulate $(\boldsymbol{a})$, NAc core $(\boldsymbol{b})$, shell $(\boldsymbol{c})$, lateral septum $(\boldsymbol{d}), \mathrm{BLA}(\boldsymbol{e}), \operatorname{PVN}(\boldsymbol{f})$, and PAG $(\boldsymbol{g} ; N=4-6$ per group). However, this defeat stress-induced increase was greater in the $\mathrm{G} / \mathrm{G}$ compared with the A/A mice within the NAc core, lateral septum, BLA, PVN, and PAG. In contrast, the G/G mice exhibited lower stress-induced Fos expression compared with the A/A mice within the prelimbic cortex. ${ }^{*} p<0.05 \mathrm{G} / \mathrm{G}$ versus $\mathrm{A} / \mathrm{A} ;{ }^{* * *} p<0.001$ compared with control; $\wedge p<0.05, \wedge \wedge p<0.01, \wedge \wedge \wedge p<0.001$, pairwise comparison $\mathrm{A} / \mathrm{A}$ Stress versus $\mathrm{G} / \mathrm{G}$ Stress.

function. We tested this hypothesis in the social-affiliation paradigm only as administration of an opioid antagonist would alter the pain associated with the physical defeat portion of the SD paradigm. In a new cohort of mice, we confirmed the increase in social affiliation in $\mathrm{G} / \mathrm{G}$ mice as evidenced by an increase in time spent sniffing the social cylinder compared with the A/A mice injected with saline ( $n=9-10$ per group; Fig. 6; group, $F_{(3,34)}=$ 2.3, $p=0.10$; cylinder, $F_{(3,34)}=97, p<0.00001$; interaction, 


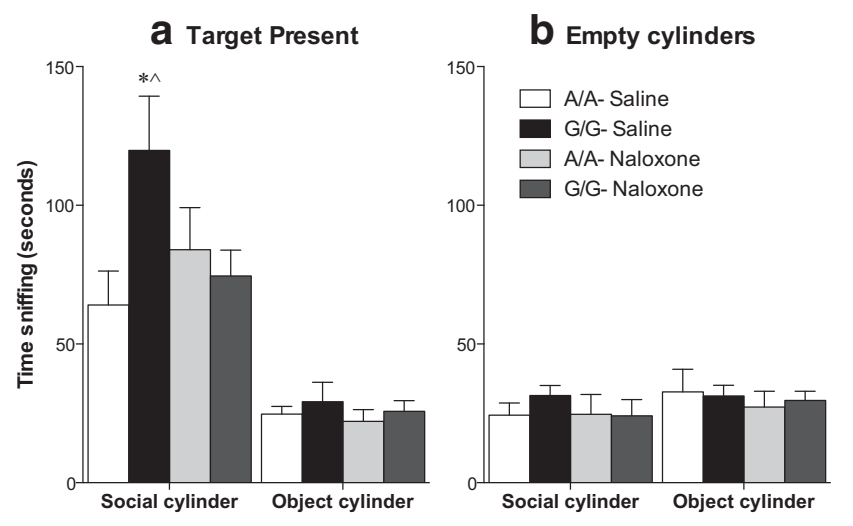

Figure 6. The increase in social affiliation in $\mathrm{G} / \mathrm{G}$ mice is blocked by naloxone. Similar to what is seen in naive mice, saline-injected $\mathrm{G} / \mathrm{G}$ mice exhibit a higher level of sociability as evidenced by increased time sniffing the social cylinder compared with the A/A mice. $\boldsymbol{a}$, However, injection of naloxone $(0.1 \mathrm{mg} / \mathrm{kg})$ blocked this effect. $\boldsymbol{b}$, No differences were seen between the two cylinders when they were empty. ${ }^{*} p<0.01$ pairwise comparison $G / G$-saline versus $A / A$-saline social cylinder sniff time; $\hat{p}<0.05$ pairwise comparison $\mathrm{G} / \mathrm{G}$-saline versus $\mathrm{G} / \mathrm{G}$-naloxone social cylinder sniff time.

$F_{(3,34)}=3.0, p=0.044$; post hoc $\mathrm{G} / \mathrm{G}$-saline vs A/A-saline, $p=$ $0.002)$. However, this increase was blocked by administration of the opioid antagonist naloxone $(0.1 \mathrm{mg} / \mathrm{kg}$, s.c.; Fig. 5; post hoc $\mathrm{G} / \mathrm{G}$-saline vs G/G-naloxone, $p=0.017)$. Naloxone had no effect in A/A mice in either time spent sniffing the object cylinder or time spent sniffing empty cylinders (Fig. 5b).

\section{Discussion}

Here we present evidence that the Oprm1 A112G SNP is associated with increased social interaction and decreased sensitivity to $\mathrm{SD}$. The resilience to SD is accompanied by a lack of anhedonic response following defeat experience as well as an increase in neural activity in response to exposure to an aggressor. We suggest that these phenotypes may be mediated by an increase in endogenous opioid release in response to social interaction, as evidenced by the ability of naloxone to block the increase in social affiliation in $\mathrm{G} / \mathrm{G}$ mice.

\section{The Oprm $1 \mathrm{G}$ allele promotes increased sociability in adult mice}

Forming positive social attachments with others is a critical aspect of emotional well-being, and impairments in the formation of these attachments may contribute to multiple psychiatric disorders. In mice with the equivalent A118G SNP, the G allele is associated with increased social interaction. This is consistent with work examining this SNP in human and primate populations. Infant primate G-allele carriers exhibit higher levels of maternal attachment than their A-allele counterparts (Barr et al., 2008). Furthermore, human G-allele carriers exhibit an increased tendency to become engaged in affectionate relationships and experience more pleasure in social situations (Troisi et al., 2011). On a broader scale, communities with higher proportions of G-allele carriers exhibit higher levels of "collectivism" rather than "individualism," suggesting that these communities may be drawn to close social attachment (Way and Lieberman, 2010).

Our data suggest that these behavioral differences between genotypes are due to an increase in endogenous opioids. This is supported by previous work demonstrating that G/G mice exhibit conditioned place aversion when given naloxone in the absence of any opioid treatment (Mague et al., 2009). An increase in endogenous opioids in G-allele carriers could be leading to a net increase in receptor activation despite the decreased number of available receptors in these mice (Mague et al., 2009; Wang et al., 2012). This is consistent with recent work using a mouse with humanized A118G SNP demonstrating that increased alcohol reward in G/G mice is blocked by opioid antagonist administration (Bilbao et al., 2014). Activation of MOPRs in the NAc leads to increased social play (Trezza et al., 2011). In MOPR knock-out mice, a loss of receptor activation leads to decreased attachment behavior (Moles et al., 2004). Thus our data support a role for increased activation of the opioid system in social interaction. The majority of work examining opioids and social behavior has focused on their role in negative affective states or "social pain," but these data suggest that the $\mu$-opioid system can play a role in positive social interactions as well.

\section{The Oprm $1 \mathrm{G}$ allele promotes resilience to SD in adult male mice}

Individuals subjected to stress exhibit a wide range of responses with some able to overcome trauma while others develop disorders, such as depression or post-traumatic stress disorder (PTSD). The ability to avoid these negative outcomes and express resilience in the face of chronic stress depends on behavioral and molecular adaptations in response to stress. The current study demonstrates that the presence of the Oprm1 G allele is associated with decreased social avoidance following SD stress. In light of the naloxone findings discussed above, it might be tempting to ascribe these findings to an increase in baseline pain thresholds. However, previous work in these mice has determined that there is no difference in hindpaw lick latency in a hot plate assay, suggesting that there is not a baseline difference in pain thresholds (Mague et al., 2009).

Therefore, to investigate whether this decreased social avoidance might be related to altered sensitivity to reward, we used the ICSS procedure and found that A/A and G/G mice do not differ in their baseline reward thresholds. Recent work by Bilbao et al. (2014) using a mouse with a humanized A118G SNP, also reports differences in baseline reward thresholds. The current study found that A/A mice exhibited significant anhedonia following $\mathrm{SD}$, which is consistent with a recent study showing that chronic SD elevates ICSS thresholds, an effect characteristic of anhedonia (Donahue et al., 2014). In contrast, G/G mice did not exhibit anhedonia following SD, suggesting that their behavioral resilience is related to adaptations in the reward system. Of interest, the more social interaction the G/G mice sought out following SD, the lower their ICSS reward threshold (Fig. 3c), suggesting that G/G mice may have found the defeat experience less aversive. In further support of this, we demonstrate that G/G mice exhibit more approach behavior during CD1 aggressor exposure (Fig. 4a). These findings are consistent with work in humans demonstrating that G-allele carriers exhibit a lower cortisol response to an acute social stress (Chong et al., 2006). Additionally, G-allele carriers exhibit improved parent-child relations in the context of parental dysfunction (Copeland et al., 2011). Consistent with this, G-allele carriers exhibit lower levels of fearful attachment in low maternal care environments (Troisi et al., 2012). Additionally, among individuals with PTSD, G carriers exhibit lower symptom severity (Nugent et al., 2012). Furthermore, work in monkeys with the ortholog SNP C77G shows a correlation between higher levels of aggression and lower levels of cortisol in $G$ carriers (Miller et al., 2004). This supports the idea that increased social dominance in G/G mice in the current study could underlie their resilience to SD. 
Resilience in Oprm1 G/G mice is accompanied by increased brain activation in stress and reward circuitry

We demonstrate that an SD experience increases c-Fos expression within known stress and reward circuitry regardless of genotype. However, G-allele carriers show significantly greater c-Fos activation in some, but not all, regions within this circuitry. An increase in neural activity is consistent with an increase in endogenous opioid expression, either at baseline or in response to specific stimuli in $\mathrm{G} / \mathrm{G}$ mice.

Our findings are consistent with work demonstrating that an increase in another Fos-family protein, $\Delta \mathrm{FosB}$, specifically within the NAc core, is associated with resilience to SD stress (Vialou et al., 2010). More recently, mice overexpressing $\Delta$ FosB were found to be resilient to the anhedonia-inducing effects of SD using the ICSS procedure (Donahue et al., 2014). Additionally, endogenous opioid expression within the NAc is negatively correlated with chronic stress-induced anhedonia (Poulin et al., 2014), supporting the idea that increased activity within the accumbens could underlie our behavioral phenotype. Although we did not explicitly examine the dopamine receptor profiles of the Fosactivated cells, previous work has demonstrated that activation of D1 medium spiny neurons in the NAc promotes resilience to SD, so it is possible that the increased activation we see in this region is primarily mediated by D1 direct pathway neurons (Francis et al., 2015).

SD stress is also known to engage the PAG (Kollack-Walker et al., 1997; Kroes et al., 2007). Specifically, repeated defeat activates and desensitizes a population of GABA neurons in the ventrolateral PAG that mediate social avoidance (Berton et al., 2007; Challis et al., 2013). We observe increased c-Fos expression in resilient G/G mice within this brain region. These results are similar to work demonstrating that rats bred for low trait anxiety exhibit higher inductions of c-Fos expression following a single SD compared with their high trait anxiety counterparts (Frank et al., 2006). As MOPR agonist administration into the PAG leads to an increase in submissive responses to SD (Vivian and Miczek, 1998), it is unlikely that an increase in endogenous opioids in this area would be causing the behavioral phenotypes seen in the present study. It is more likely that the decreased MOPR activity, resulting from decreased receptor expression in these mice (Mague et al., 2009), is playing a role in the increased resilience seen in the G/G mice. Although MOPRs are often localized on GABAergic interneurons in the PAG, there is also evidence that these receptors can directly inhibit PAG output neurons (Commons et al., 2000). Therefore, it is also possible that the increased activation of cFos seen in $\mathrm{G} / \mathrm{G}$ mice in the PAG is a result of decreased MOPR-mediated inhibition of output neurons following SD stress.

Animals with low trait anxiety also exhibit higher levels of defeat-induced c-Fos expression within the PVN (Frank et al., 2006). This is consistent with our finding that resilient G/G mice exhibit higher Fos expression within the PVN compared with the vulnerable A/A mice. Furthermore, projections from the PAG to the PVN are thought to mediate the behavioral responses to SD (Floyd et al., 1996), suggesting that alterations in MOPR expression within the PAG could affect activation of the PVN.

The increased activation in the lateral septum in G/G mice following SD may also play a role in their resilient phenotype. Activation of the lateral septum by SD leads to an increase in oxytocin release, and this increase is higher in dominant compared with submissive animals (Timmer et al., 2011). Consistent with this, G/G mice exhibit greater social dominance compared with A/A mice (Fig. 4), along with decreased submissive behavior seen in response to the aggressor in the G/G mice (Fig. $5 a$ ). Dominant rodents within a hierarchy do not express SD behavior and exhibit increased social interaction (Morrison et al., 2011, 2012). G/G mice show social dominance, resilience to SD, and increased social interaction. The largest differential activation of c-Fos between $A / A$ and G/G mice is seen in the lateral septum. Thus, this regions may be an important neural substrate to investigate for additional molecular mechanisms that mediate the behavioral consequences of the Oprm1 A118G SNP.

Social rejection is a form of social stress. Human studies show that social rejection significantly activates the MOPR system in a number of important brain regions associated with reward (ventral striatum), fear (amygdala), and pain (PAG; Hsu et al., 2013). Additional work in animals also supports the idea that social conflict activates the opioid system (Teskey et al., 1984). In the current study, we demonstrate that G/G mice exhibit increased $c$-Fos expression in response to aggressor exposure within the ventral striatum (NAc core), amygadala (BLA), and the PAG. As opioid receptors are typically located on GABA terminals, greater inhibition of GABA neurons by MOPRs coupled to Gi signaling cascades would effectively activate any postsynaptic neurons.

It should be noted that some work in human populations has shown that $G$ carriers exhibit an increased sensitivity to social rejection (Way et al., 2009; Slavich et al., 2010). However, in humans, this response to social rejection is associated with increases in activity within the anterior cingulate (Hsu et al., 2013) and we did not find differences in defeat-induced c-Fos expression within this region, suggesting that social rejection stress may engage different brain circuits compared with SD stress.

\section{Conclusion}

A critical mass of studies links the OPRM1 A118G SNP with alterations in social behavior. However, these data are somewhat contradictory. Thus, modeling this SNP in mice is important to help clarify inconsistencies associated with human data, and to provide information on the specificity of the SNP in well controlled behavioral phenotypes. The results from A112G mice suggest that G-allele carriers exhibit increased sociability, dominance, and decreased vulnerability to social stress, and this may be mediated by an increase in endogenous opioid tone. Future studies using this mouse model could serve as a valuable tool in determining more precise molecular mechanisms of social affiliation and social stress resilience and potentially provide novel avenues of exploration for therapeutic targets.

\section{References}

American Psychiatric Association (2013) Diagnostic and statistical manual of mental disorders, fifth edition. Arlington, VA: American Psychiatric.

Barr CS, Schwandt ML, Lindell SG, Higley JD, Maestripieri D, Goldman D, Suomi SJ, Heilig M (2008) Variation at the mu-opioid receptor gene (OPRM1) influences attachment behavior in infant primates. Proc Natl Acad Sci U S A 105:5277-5281. CrossRef Medline

Baumeister RF, DeWall CN, Ciarocco NJ, Twenge JM (2005) Social exclusion impairs self-regulation. J Pers Soc Psychol 88:589-604. CrossRef Medline

Bergen AW, Kokoszka J, Peterson R, Long JC, Virkkunen M, Linnoila M, Goldman D (1997) Mu opioid receptor gene variants: lack of association with alcohol dependence. Mol Psychiatry 2:490-494. CrossRef Medline

Bertoletti E, Zanoni A, Giorda R, Battaglia M (2012) Influence of the OPRM1 gene polymorphism upon children's degree of withdrawal and brain activation in response to facial expressions. Dev Cogn Neurosci 2:103-109. CrossRef Medline 
Berton O, Covington HE 3rd, Ebner K, Tsankova NM, Carle TL, Ulery P, Bhonsle A, Barrot M, Krishnan V, Singewald GM, Singewald N, Birnbaum S, Neve RL, Nestler EJ (2007) Induction of deltaFosB in the periaqueductal gray by stress promotes active coping responses. Neuron 55 : 289-300. CrossRef Medline

Bilbao A, Robinson JE, Heilig M, Malanga CJ, Spanagel R, Sommer WH, Thorsell A (2014) A pharmacogenetic determinant of mu-opioid receptor antagonist effects on alcohol reward and consumption: evidence from humanized mice. Biol Psychiatry pii:S0006-3223(14)00653-2. CrossRef Medline

Brodkin ES, Hagemann A, Nemetski SM, Silver LM (2004) Social approachavoidance behavior of inbred mouse strains towards DBA/2 mice. Brain Res 1002:151-157. CrossRef Medline

Carlezon WA Jr, Chartoff EH (2007) Intracranial self-stimulation (ICSS) in rodents to study the neurobiology of motivation. Nat Protoc 2:29872995. CrossRef Medline

Chaijale NN, Curtis AL, Wood SK, Zhang XY, Bhatnagar S, Reyes BA, Van Bockstaele EJ, Valentino RJ (2013) Social stress engages opioid regulation of locus coeruleus norepinephrine neurons and induces a state of cellular and physical opiate dependence. Neuropsychopharmacology 38 : 1833-1843. CrossRef Medline

Challis C, Boulden J, Veerakumar A, Espallergues J, Vassoler FM, Pierce RC, Beck SG, Berton O (2013) Raphe GABAergic neurons mediate the acquisition of avoidance after social defeat. J Neurosci 33:13978-13988, 13988a. CrossRef Medline

Chong RY, Oswald L, Yang X, Uhart M, Lin PI, Wand GS (2006) The mu-opioid receptor polymorphism A118G predicts cortisol responses to naloxone and stress. Neuropsychopharmacology 31:204-211. Medline

Commons KG, Aicher SA, Kow LM, Pfaff DW (2000) Presynaptic and postsynaptic relations of mu-opioid receptors to gamma-aminobutyric acidimmunoreactive and medullary-projecting periaqueductal gray neurons. J Comp Neurol 419:532-542. CrossRef Medline

Copeland WE, Sun H, Costello EJ, Angold A, Heilig MA, Barr CS (2011) Child mu-opioid receptor gene variant influences parent-child relations. Neuropsychopharmacology 36:1165-1170. CrossRef Medline

Donahue RJ, Muschamp JW, Russo SJ, Nestler EJ, Carlezon WA Jr (2014) Effects of striatal $\Delta$ FosB overexpression and ketamine on social defeat stress-induced anhedonia in mice. Biol Psychiatry 76:550-558. CrossRef Medline

Floyd NS, Keay KA, Arias CM, Sawchenko PE, Bandler R (1996) Projections from the ventrolateral periaqueductal gray to endocrine regulatory subdivisions of the paraventricular nucleus of the hypothalamus in the rat. Neurosci Lett 220:105-108. CrossRef Medline

Francis TC, Chandra R, Friend DM, Finkel E, Dayrit G, Miranda J, Brooks JM, Iniguez SD, O’Donnell P, Kravitz A, Lobo MK (2015) Nucleus accumbens medium spiny neuron subtypes mediate depression-related outcomes to social defeat stress. Biol Psychiatry 77:212-222. CrossRef Medline

Frank E, Salchner P, Aldag JM, Salomé N, Singewald N, Landgraf R, Wigger A (2006) Genetic predisposition to anxiety-related behavior determines coping style, neuroendocrine responses, and neuronal activation during social defeat. Behav Neurosci 120:60-71. CrossRef Medline

Franklin K, Paxinos G (2007) The mouse brain in stereotaxic coordinates, 3rd edition. San Diego: Academic.

Gelernter J, Kranzler H, Cubells J (1999) Genetics of two mu opioid receptor gene (OPRM1) exon I polymorphisms: population studies, and allele frequencies in alcohol- and drug-dependent subjects. Mol Psychiatry 4:476-483. CrossRef Medline

Herman BH, Panksepp J (1978) Effects of morphine and naloxone on separation distress and approach attachment: evidence for opiate mediation of social affect. Pharmacol Biochem Behav 9:213-220. CrossRef Medline

Hsu DT, Sanford BJ, Meyers KK, Love TM, Hazlett KE, Wang H, Ni L, Walker SJ, Mickey BJ, Korycinski ST, Koeppe RA, Crocker JK, Langenecker SA, Zubieta JK (2013) Response of the mu-opioid system to social rejection and acceptance. Mol Psychiatry 18:1211-1217. CrossRef Medline

Huang P, Chen C, Mague SD, Blendy JA, Liu-Chen LY (2012) A common single nucleotide polymorphism A118G of the mu opioid receptor alters its N-glycosylation and protein stability. Biochem J 441:379-386. CrossRef Medline
Kalin NH, Shelton SE, Lynn DE (1995) Opiate systems in mother and infant primates coordinate intimate contact during reunion. Psychoneuroendocrinology 20:735-742. CrossRef Medline

Knowles PA, Conner RL, Panksepp J (1989) Opiate effects on social behavior of juvenile dogs as a function of social deprivation. Pharmacol Biochem Behav 33:533-537. CrossRef Medline

Kollack-Walker S, Watson SJ, Akil H (1997) Social stress in hamsters: defeat activates specific neurocircuits within the brain. J Neurosci 17:88428855. Medline

Kroes RA, Burgdorf J, Otto NJ, Panksepp J, Moskal JR (2007) Social defeat, a paradigm of depression in rats that elicits $22 \mathrm{kHz}$ vocalizations, preferentially activates the cholinergic signaling pathway in the periaqueductal gray. Behav Brain Res 182:290-300. CrossRef Medline

Mague SD, Blendy JA (2010) OPRM1 SNP (A118G): involvement in disease development, treatment response, and animal models. Drug Alcohol Depend 108:172-182. CrossRef Medline

Mague SD, Isiegas C, Huang P, Liu-Chen LY, Lerman C, Blendy JA (2009) Mouse model of OPRM1 (A118G) polymorphism has sex-specific effects on drug-mediated behavior. Proc Natl Acad Sci U S A 106:10847-10852. CrossRef Medline

Mallott MA, Maner JK, DeWall N, Schmidt NB (2009) Compensatory deficits following rejection: the role of social anxiety in disrupting affiliative behavior. Depress Anxiety 26:438-446. CrossRef Medline

Messeri P, Eleftheriou BE, Oliverio A (1975) Dominance behavior: a phylogenetic analysis in the mouse. Physiol Behav 14:53-58. CrossRef Medline

Miller GM, Bendor J, Tiefenbacher S, Yang H, Novak MA, Madras BK (2004) A mu-opioid receptor single nucleotide polymorphism in rhesus monkey: association with stress response and aggression. Mol Psychiatry 9:99108. CrossRef Medline

Moles A, Kieffer BL, D'Amato FR (2004) Deficit in attachment behavior in mice lacking the mu-opioid receptor gene. Science 304:1983-1986. CrossRef Medline

Morrison KE, Swallows CL, Cooper MA (2011) Effects of dominance status on conditioned defeat and expression of 5-HT1A and 5-HT2A receptors. Physiol Behav 104:283-290. CrossRef Medline

Morrison KE, Curry DW, Cooper MA (2012) Social status alters defeatinduced neural activation in Syrian hamsters. Neuroscience 210:168-178. CrossRef Medline

Moy SS, Nadler JJ, Young NB, Perez A, Holloway LP, Barbaro RP, Barbaro JR, Wilson LM, Threadgill DW, Lauder JM, Magnuson TR, Crawley JN (2007) Mouse behavioral tasks relevant to autism:phenotypes of 10 inbred strains. Behav Brain Res 176:4-20. CrossRef Medline

Nugent NR, Lally MA, Brown L, Knopik VS, McGeary JE (2012) OPRM1 and diagnosis-related posttraumatic stress disorder in binge-drinking patients living with HIV. AIDS Behav 16:2171-2180. CrossRef Medline

Panksepp J, Herman B, Conner R, Bishop P, Scott JP (1978) The biology of social attachments: opiates alleviate separation distress. Biol Psychiatry 13:607-618. Medline

Paxinos G, Franklin K (2004) The mouse brain in stereotaxic coordinates, compact 2nd edition. Amsterdam: Elsevier Academic.

Poulin JF, Laforest S, Drolet G (2014) Enkephalin downregulation in the nucleus accumbens underlies chronic stress-induced anhedonia. Stress 17:88-96. CrossRef Medline

Slavich GM, O’Donovan A, Epel ES, Kemeny ME (2010) Black sheep get the blues: a psychobiological model of social rejection and depression. Neurosci Biobehav Rev 35:39-45. CrossRef Medline

Tan EC, Tan CH, Karupathivan U, Yap EP (2003) Mu opioid receptor gene polymorphisms and heroin dependence in Asian populations. Neuroreport 14:569-572. CrossRef Medline

Teskey GC, Kavaliers M, Hirst M (1984) Social conflict activates opioid analgesic and ingestive behaviors in male mice. Life Sci 35:303-315. CrossRef Medline

Timmer M, Cordero MI, Sevelinges Y, Sandi C (2011) Evidence for a role of oxytocin receptors in the long-term establishment of dominance hierarchies. Neuropsychopharmacology 36:2349-2356. CrossRef Medline

Trezza V, Damsteegt R, Achterberg EJ, Vanderschuren LJ (2011) Nucleus accumbens $\mu$-opioid receptors mediate social reward. J Neurosci 31: 6362-6370. CrossRef Medline

Troisi A, Frazzetto G, Carola V, Di Lorenzo G, Coviello M, D’Amato FR, Moles A, Siracusano A, Gross C (2011) Social hedonic capacity is asso- 
ciated with the A118G polymorphism of the mu-opioid receptor gene (OPRM1) in adult healthy volunteers and psychiatric patients. Soc Neurosci 6:88-97. CrossRef Medline

Troisi A, Frazzetto G, Carola V, Di Lorenzo G, Coviello M, Siracusano A, Gross C (2012) Variation in the mu-opioid receptor gene (OPRM1) moderates the influence of early maternal care on fearful attachment. Soc Cogn Affect Neurosci 7:542-547. CrossRef Medline

Vialou V, Robison AJ, Laplant QC, Covington HE 3rd, Dietz DM, Ohnishi YN, Mouzon E, Rush AJ 3rd, Watts EL, Wallace DL, Iñiguez SD, Ohnishi YH, Steiner MA, Warren BL, Krishnan V, Bolaños CA, Neve RL, Ghose S, Berton O, Tamminga CA et al. (2010) DeltaFosB in brain reward circuits mediates resilience to stress and antidepressant responses. Nat Neurosci 13:745-752. CrossRef Medline

Vivian JA, Miczek KA (1998) Effects of mu and delta opioid agonists and antagonists on affective vocal and reflexive pain responses during social stress in rats. Psychopharmacology 139:364-375. CrossRef Medline

Wang YJ, Huang P, Ung A, Blendy JA, Liu-Chen LY (2012) Reduced expression of the mu opioid receptor in some, but not all, brain regions in mice with OPRM1 A112G. Neuroscience 205:178-184. CrossRef Medline

Way BM, Lieberman MD (2010) Is there a genetic contribution to cultural differences? Collectivism, individualism and genetic markers of social sensitivity. Soc Cogn Affect Neurosci 5:203-211. CrossRef Medline

Way BM, Taylor SE, Eisenberger NI (2009) Variation in the mu-opioid receptor gene (OPRM1) is associated with dispositional and neural sensitivity to social rejection. Proc Natl Acad Sci U S A 106:15079-15084. CrossRef Medline

Williams KD (2007) Ostracism. Annu Rev Psychol 58:425-452. CrossRef Medline 